\title{
Microscopic-Based Trend in Imported Malaria among Workers of Trenggalek District Returning from Kalimantan Island, Indonesia During 2012 - 2016
}

\author{
Heny Arwati ${ }^{1 *}$, Kusmartisnawati ${ }^{1}$, Subagyo Yotopranoto ${ }^{1}$, Poppy Hidayat ${ }^{2}$, Yoes Prijatna Dachlan ${ }^{1}$ \\ ${ }^{1}$ Department of Parasitology, Faculty of Medicine, Universitas Airlangga, Surabaya 60131, Indonesia \\ ${ }^{2}$ Pandean Primary Health Center, Trenggalek 66363, Indonesia
}

Article history:

Submission October 2018

Revised January 2019

Accepted January 2019

*Corresponding author:

E-mail: arwatiheny@gmail.com

\begin{abstract}
Malaria in Indonesia remains a significant health problem. Trenggalek District is one of the receptive malaria areas in East Java Province, Indonesia, with mainly imported malaria from outside Java Island. The people of this district accustomed to traveling to outside Java where malaria is endemic for temporary working purposes. Usually, they have acquired malaria infection in the areas where they worked and brought to their homeland during their return to the district. The number of imported malaria cases depend on the returning season of the workers. When no workers return from outside Java malaria case is zero. During the year of 2012-2016 microscopic examination of Microscopic examination of Giemsa-stained thick blood films of the workers have been done in the working activity of Pandean Primary Health Center on their arrival from Kalimantan Island either by active or passive case detection. Microscopically positive data were reported herein to describe the trend of imported malaria in the studied areas. A total number of malaria-infected workers were 118 cases. The trend towards increasing case number yearly between 2012 and 2013 being 1.35\%, then decreasing between 2013 and 2016 to only 4 cases in 2016. Different patterns of imported malaria by month were seen in each year but no specific pattern throughout the year. The Plasmodium vivax infection was predominant every year and followed by Plasmodium falciparum and mixed infection of those two species. Trends of imported malaria cases in Trenggalek district were decreased and increased irregularly in each month yearly. However, the number of cases declined annually during 2013 - 2016. Antimalarial prophylaxis and insecticides prevent the workers from malaria infection.
\end{abstract}

Keywords: Imported malaria, Trenggalek district, Pandean Primary Health Center

\section{Introduction}

Malaria is an infectious disease caused by protozoan of genus Plasmodium. This disease in human caused by Plasmodium falciparum, Plasmodium vivax, Plasmodium malariae and Plasmodium ovale [1]. A species of Plasmodium knowlesi that primarily caused malaria in primates, recently has been reported to infect human [2]. Malaria is transmitted by Anopheles mosquito from an infected person to others and affect mankind with the burden of disease [3]. In 2016, an estimated 216 million cases of malaria oc- curred worldwide, compared with 211 million in 2015. Of the 91 countries reporting indigenous malaria cases [4]. On the other hand, imported malaria became a severe health problem in some nonendemic countries, such as China [5], UK [6], and Mediterranean countries [7]. In Indonesia, imported malaria cases have been reported from Jakarta [8] and Sukabumi District of West Java Province [9]. The importation of malaria to nonendemic areas has been reported to increase the risk of malaria reintroduction [5].

\section{How to cite:}

Arwati H, Kusmartisnawati, Yotopranoto S, Hidayat P (2019) Microscopic-Based Trend in Imported Malaria among Workers of Trenggalek District Returning from Kalimantan Island, Indonesia During 2012 - 2016. Journal of Tropical Life Science 9 (1): 105 - 110. doi: 10.11594/jtls.09.01.14 
Malaria is imported into a malaria-free area as a result of human migration. Thus, imported malaria is described as an infection that is acquired in an endemic area by an individual, but diagnosed in a malaria-free area either microscopically or clinically [10]. The length of time visit endemic countries varies among the nations [11]. WHO has classified malaria infection as imported based on three months period of visiting the endemic country [12], while other countries used different criteria [13, 14]. Malaria importation can be identified as four stages of people movement as described while people are in malaria eliminating region, during transit, in the endemic region, and upon return to the eliminating country. Some malaria interventions can be applied to each stage to prevent acquisition or transmission of imported malaria [12].

Trenggalek District is one of the hypo endemic malaria areas where malaria outbreaks have occurred during 2006, 2007 and 2008. Dongko subdistrict is one of the malaria endemic areas among five subdistricts in Trenggalek district those remains endemic [15]. Malaria cases in this subdistrict were contributed with imported cases. The people of Trenggalek District accustomed to transmigrate to outside Java Island, where malaria is endemic, for temporary working purposes [16]. Usually, they have acquired malaria infection during their stay in those areas and brought back to their homeland as demonstrated by the data recorded by Pandean Primary Health Center (PHC) in Dongko subdistrict, Trenggalek district, East Java Province during a period 2012 to 2016. This report described a data of imported malaria brought by labor workers returning from temporary working in Kalimantan Island, Indonesia, who have checked their blood films on their arrival.

\section{Material and Methods Location}

Trenggalek is a district located in the southern part of East Java Province. This district is located at coordinates $111^{\circ} 24$ ' up to $112^{\circ} 11$ ' east longitude and $7^{\circ} 63$ ' until $8^{\circ} 34$ ' south latitude. Trenggalek mainly composed of mountainous land with an area covering $2 / 3$ of the total area. As for the rest of this $(1 / 3)$ is a low-lying land. The height of land is between 0 and 690 meters above sea level. Pacitan and Ponorogo Districts border
Trenggalek District to the West, Ponorogo and Tulungagung Districts to the North, Tulungagung Regency to the East, and Indonesian Ocean to the South [17].

\section{Data collection}

The data of microscopic examination of imported malaria collected by Pandean PHC over period 2012 - 2016 including other characteristic and information of patients. The data were obtained from villagers who diagnosed microscopically infected with malaria upon their arrival from three months temporary working in Kalimantan Island. Microscopic examinations were done by the trusted analyst on Giemsa-stained blood films taken by finger-prick.

\section{Results and Discussion Number of cases}

A total number of imported malaria cases in Pandean PHC throughout 2012-2016 were 118 cases consisted of 34 (28.81\%), 46 (38.98\%), 26 (22.03\%), 8 (6.78\%) and 4 (4.40\%) cases respectively. The trend is increased from 2012 to 2013 but decreased yearly from 2013 to the lowest number in 2016. During 2012 a villager was reported suspected autochthonous malaria with fever. However, no parasite was found on his blood film by microscopic examination. Following this case, malaria cases in Pandean PHC were always imported cases [18].

\section{Characteristic of patients}

All patients were male workers and mostly were a productive group of ages, they were between 18 to 60 years old. Most patients were on 20 - 30 years old (54.24\%). The youngest patients were one person of 18 years old and two persons were 19 years old in 2013. The oldest patient was one person of 60 years old and also found in 2013 (Table 1).

\section{Origins of cases}

All the patients have traveled to Kalimantan Island mainly to the provinces of East Kalimantan (Berau District, Sepaku Subdistrict), Central Kalimantan and South Kalimantan provinces. Main jobs were laborer of palm oil plantation (Elaeis guineesis), the plant that is used in commercial agriculture in the production of palm oil. The social and economic factors apparently 
caused the temporary transmigration of Treng- income. One reason galek's people outside Java Island to earn more

Table 1. Number (\%) of imported malaria patients based on group of age

\begin{tabular}{ccccccc}
\hline \multirow{2}{*}{$\begin{array}{c}\text { Age } \\
\text { (years) }\end{array}$} & \multicolumn{5}{c}{ Total (\%) } & Grand Total \\
\cline { 2 - 6 } & 2012 & 2013 & 2014 & 2015 & 2016 & $(\%)$ \\
\hline $18-19$ & $0(0)$ & $3(2.54)$ & $0(0)$ & $0(0)$ & $0(0)$ & $3(2.54)$ \\
$20-30$ & $13(11.01)$ & $29(24.58)$ & $16(13.56)$ & $4(3.39)$ & $2(1.69)$ & $64(54.24)$ \\
$31-40$ & $13(11.01)$ & $7(5.03)$ & $9(7.63)$ & $2(1.69)$ & $2(1.69)$ & $33(27.97)$ \\
$41-50$ & $7(5.03)$ & $5(4.24)$ & $0(0)$ & $1(0.85)$ & $0(0)$ & $13(11.02)$ \\
$51-60$ & $1(0.85)$ & $2(1.69)$ & $1(0.85)$ & $1(0.85)$ & $0(0)$ & $5(4.24)$ \\
\hline Total (\%) & $34(28.81)$ & $46(38.98)$ & $26(22.03)$ & $8(6.78)$ & $4(3.39)$ & $118(100)$ \\
\hline
\end{tabular}

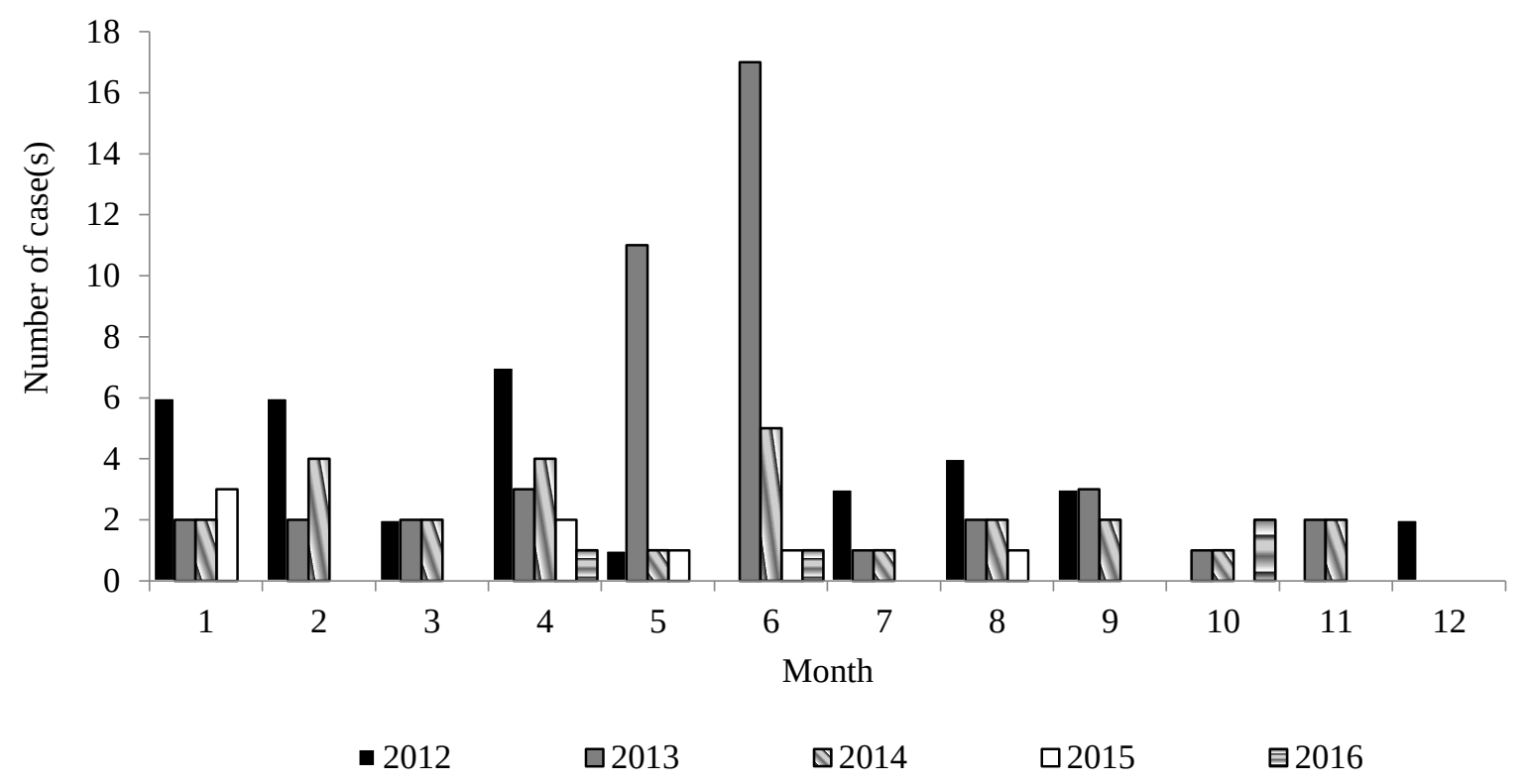

Figure 1. Monthly trend of imported malaria cases in former migrant workers in Pandean PHC during 2012 2016 respectively

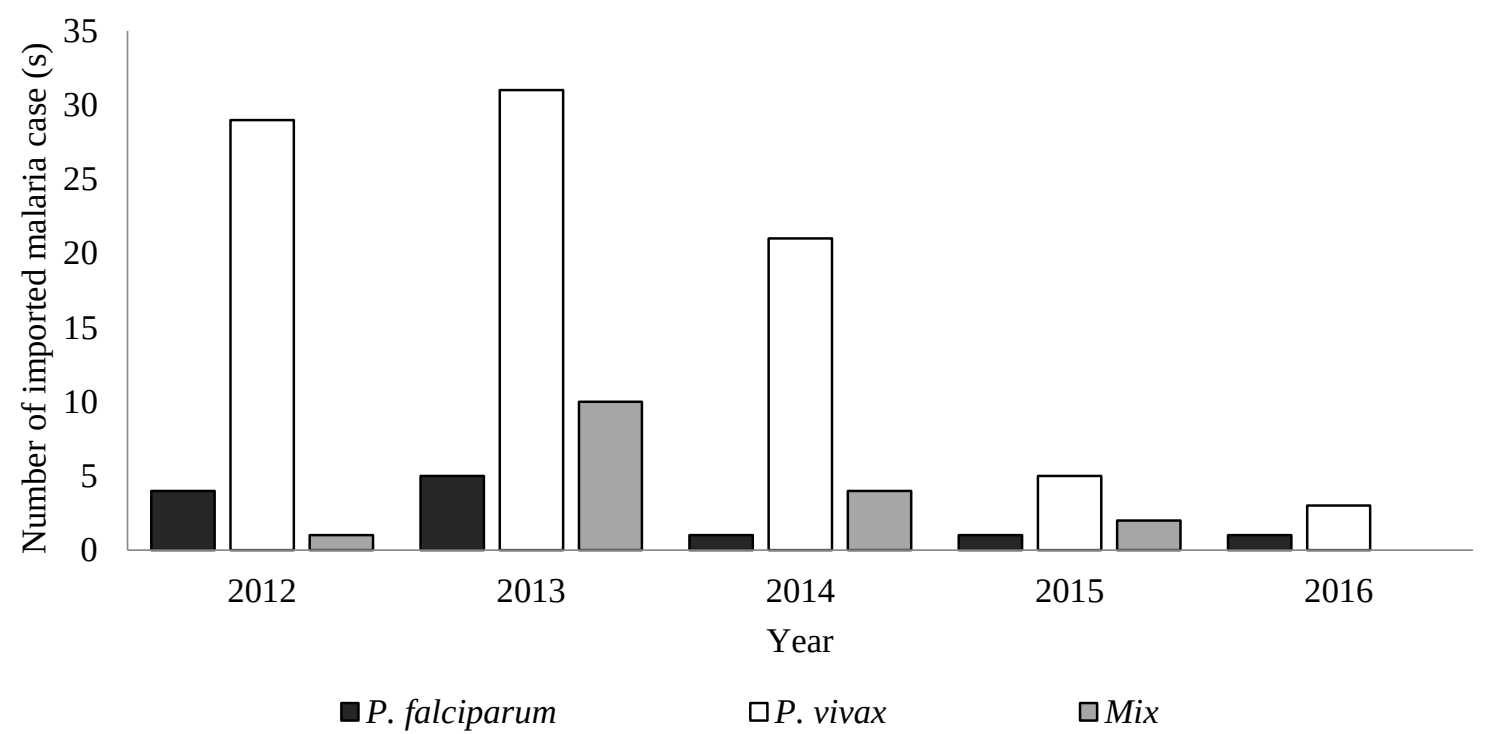

Figure 2. Number of imported malaria cases by species among former migrant workers reported by Pandean ${ }^{2019}$ PHC in each year of $2012-2016$ 
for their transmigration is that the employment opportunities in their villages are minimal. Unfortunately, it is followed by the increased of malaria infection brought by them during their return home. The factors associated with people movement include economic necessity, poverty, civil conflict and natural disasters [19, 20] contribute to the increase of malaria importation [21].

\section{Monthly trends of imported malaria}

The trend of imported malaria in Pandean PHC by month in each year showed that there was no specific pattern of imported malaria each month throughout the year. Monthly total number of imported malaria increased and decreases irregularly. Peaks occurred differently over each year. During 2012 peaks occurred in April, 2013 in May and June, and 2014 in June only. Zero cases were found in June, October and November of 2012, and December of 2013 and 2014, respectively (Figure 1).

The highest number of imported malaria in June may be related to the effort to earn more income to meet the expense of the new academic year of school entrance for their children. The importations of malaria were low during Muslim holiday vacation in August/October 2012-2014, probably caused by the decreased demand of workers in their working areas. The pattern of imported malaria in Pandean PHC is different from that in Jakarta, the capital city of Indonesia. The high peak of imported malaria in Jakarta occurred during school vacation and Muslim holidays vacation (Iedul Fitr) in June/July [8]. Fluctuation of imported malaria cases in Pandean PHC is seasonally depending upon the season where the workers return from outside Java to their homeland. However, due to better prevention of infection, since 2015 the number of cases decreased sharply. The number of Trenggalek's people and the schedule for their departure are uncertain. Therefore, there is no specific pattern of imported malaria cases fluctuation in Pandean PHC. The figure of imported malaria in Indonesia is different as reported in Jakarta8 and Sukabumi District [9]. In Jakarta, the capital of Indonesia, the imported malaria was reported among active duty military and civilian after traveling to Papua Province and South Sumatra (Bangka Island and Lampung Province) Indonesia [8]. The imported malaria in Sukabumi District of West Java Province were reported majority from the people who worked in the mining sector those mostly working in night shift in Sumatra Island, Sulawesi, Nusa Tenggara and Papua. This particular group of travelers are the high risk of infection due to the activities in malaria endemic areas are often resulted in imported malaria cases [9]. Population mobility to outside Java Island and vise versa contributed to the complexities of risk of malaria infection in Indonesian archipelago.

\section{Microscopic examination}

Microscopic examination of total 118 blood films showed that $P$. vivax was predominantly found in each year. Total $P$. vivax-containing blood films were $89(75.42 \%)$. They were 29 (24.57\%), 31 (26.27\%), 21 (17.80\%), 5 (4.24\%) and 3 (2.54\%) since 2012 to 2016 respectively. Secondly was $P$. falciparum infection, those were 12 (10.17\%) consisted of 4 (3.39\%), 5 (4.24\%), 1 (0.85\%), $1(0.85 \%)$ and $1(0.85 \%)$ and followed by mix infection were $21(17.80 \%)$ those containing of 1 (0.85\%), 10 (8.47\%), 4 (3.39\%), 2 (1.69\%) dan 4 (3.39\%) during 2012-2016 respectively (Figure 2).

The workers returning from Kalimantan Island mostly were infected with $P$. vivax (Figure 2). Eastern parts of Indonesia are more common stable transmission zones of $P$. vivax than western parts [22], although $P$. falciparum is also common in Kalimantan Island [23]. The P. vivax infection in Kalimantan Island based on annual parasite incidence (API) are between $<0.1$ to $\geq$ $0.1 \%$ depend on the provinces [22]. Large areas of malaria vivax transmission were found in most areas of Kalimantan and Sumatra Islands with a low level of endemicity than eastern regions of Indonesia [24].

The imported malaria cases in the People Republic of China were also reported in the labourers returning from Africa and South East Asian countries [25]. In the UK, the cases were reported among people who travel to visit friends and relatives to West African countries [6]. These groups of travelers constitute are at the high risk for importing malaria [25].

Activities involving population or individual movement to and from endemic malaria areas contributed to the spread [26], importation [27], and transmission $[28,20]$ of the disease, may also 
reintroduce the disease to endemic and nonendemic areas [11]. The imported malaria often results in delays in diagnosis, expensive to treat, cause secondary local transmission and may contribute to the spread of antimalarial drug resistance and threaten long-term eradication goals [29]. Imported malaria caused not only the differences in the epidemiology of the disease but also clinical severity of malaria between both zones, ecological characteristic, circulating malaria parasites and population characteristic [21]. The Imported malaria should be addressed to achieve malaria elimination [12]. Trenggalek District as a receptive area with the existence of anopheline mosquito and other ecological and climate factors that favoring malaria transmission need to reduce receptivity by the use of insecticides such as larvicide, adulticide and repellent. Furthermore, asymptomatic malaria cases have been discovered [16] and in 2016 submicroscopic malaria cases have been proved play a role in malaria transmission in this area [30] however, in 2017 no indigenous malaria transmission has been reported [31].

Recently, the Pandean PHC has provided a malaria chemoprophylaxis drug to the workers before leaving for endemic areas to prevent the importation of malaria. The workers were given doxycycline at a dose of $2 \mathrm{mg} / \mathrm{kg}$ body weight for four weeks, more than that they were recommended to use insecticides or repellent to ovoid mosquito bites especially at night. Following this intervention, elimination malaria has been achieved by Trenggalek District in 2017 since no indigenous malaria has been found [32].

\section{Conclusion}

The trends of imported malaria in Trenggalek district depend on the fluctuation of returning migrant workers from outside Java. In addressing imported malaria to maintain the free malaria area of this district, the chemoprofilaxys should be provided by the health center to the villagers before transmigrating to endemic areas in outside Java Island. The workers may also use insecticide or bednet to prevent mosquito bites during their stay in malarious areas. On the other hand, the microscopic examination of their blood should always be performed upon their arrival in their homeland.

\section{Acknowledgment}

We would like to thank the head and staffs of the Ministry of Health in Trenggalek District as well as the head and staffs of Pandean PHC for allowing us to do malaria research in Pandean PHC and its working activity areas. This research was supported by DIPA Universitas Airlangga No: 2613/H3/KR/2012, the Indonesian Ministry of Research, Technology and High Education.

\section{References}

1. Tarantola A, Rachline A, Konto C et al. (2005) Occupational Plasmodium falciparum malaria following accidental blood exposure: a case, published reports and considerations for postexposure prophylaxis. Scandinavian Journal of Infectious Diseases 37 (2): $131-140$.

2. Singh B, Kim SL, Matusop A et al. (2004) A large focus of naturally acquired Plasmodium knowlesi infections in human beings. The Lancet 363 (9414): 1017 - 1024. doi: 10.1016/S0140-6736(04)15836-4.

3. White NJ, Pukrittayakamee S, Hien TT et al. (2015) WHO: Global technical strategy for malaria 2016 - 2030. https://www.who.int/. Accessed: September 2018.

4. World Health Organization (2017) World malaria report 2017. https://www.who.int/. Accessed: September 2018.

5. Zhou S, Li Z, Cotter C et al. (2016) Trends of imported malaria in China 2010-2014: analysis of surveillance data. Malaria Journal 15: 39. doi: 10.1186/s12936-016-1093-0

6. Behrens, RH, Neave PE, Jones COH (2015) Imported malaria among people who travel to visit friends and relatives: Is current UK policy effective or does it need a strategic change?. Malaria Journal 14: 149. doi: 10.1186/s12936-015-0666-7

7. Odolini S, Gautret P, Parola P (2012) Epidemiology of imported malaria. Mediterranean Journal of Hematology and Infectious Diseases 4 (1): e201. doi: 10.4084/MJHID.2012.031.

8. Lederman ER, Sutanto I, Wibudi A et al. (2006) Imported malaria in Jakarta, Indonesia: Passive surveillance of returned travelers and military members postdeployment. Journal of Travel Medicine 13 (3): 153 - 160. doi: 10.1111/j.17088305.2006.00034.x.

9. Eryando T, Susanna D, Pratiwi D, Nugraha F (2012) Imported malaria cases in Sukabumi District-West Java Indonesia, in 2012. Malaria Journal 11 (Suppl 1): P94. doi: 10.1186/14752875-11-S1-P94.

10. Muentener P, Schlagenhauf P, Steffen R (1999) Imported malaria (1985 - 95): Trends and perspectives. Bulletin of the World Health Organization 77 (7): 560 - 566.

11. Sturrock HJW, Roberts KW, Wegbreit J et al. (2015) Tackling imported malaria: An elimination endgame. The American Journal of Tropical Medicine and Hygiene 93 (1): 139 - 144 doi:10.4269/ajtmh.14-0256. 
12. World Health Organization (2012) Disease surveillance for malaria: An operational manual. https://www.who.int/. Accessed: September 2018.

13. Gueye CS, Sanders KC, Galappaththy GNL et al. (2013) Active case detection for malaria elimination: A survey among Asian Pacific countries. Malaria Journal 12: 358. doi: 10.1186/1475-2875-12-358.

14. Galappaththy GN, Fernando SD, Abeyasinghe RR (2013) Imported malaria: A possible threat to the elimination of malaria from Sri Lanka?. Tropical Medicine and International Health 18 (6): 761 - 768. doi: 10.1111/tmi.12097

15. Sur (2009) Lima kecamatan di Trenggalek endemis malaria. http://surabaya.tribunnews.com/. Accessed: 20 July 2016.

16. Arwati H, Kusmartisnawati, Poppy, Dachlan YP (2013) Asymptomatic malaria in Trenggalek District, East Java Province as revealed by microscopic examination and single step PCR. Folia Medica Indonesiana 49 (3): 150 - 154.

17. Trenggalek Regency Government (2016) Geografi Kabupaten Trenggalek. http://www.trenggalekkab.go.id/. Accessed $20 \mathrm{Ju}-$ ly 2016

18. Pandean Community Health Center (2017) Data malaria of Pandean Community Health Center. Trenggalek, Pandean Community Health Center.

19. Breman J, Alilio M, Mills A (2004) Conquering the intolerable burden of malaria: What's new, what 's needed: A summary. The American Journal of Tropical Medicine and Hygiene 71 (Suppl 2): 1 - 15.

20. Marten P, Hall L (2000) Malaria in the move: Human population movement and malaria transmission. Emerging Infectious Diseases 6 (2): 1003 - 1107. doi: 10.3201/eid0602.000202.

21. Rodrigues-Morales AJ, Delgado L, Martinez N, FrancoParedes C (2006) Impact of imported malaria on the burden of disease in Northeastern Venezuela. Journal of Travel Medicine 13 (1): 15 - 20. doi: 10.1111/j.1708-8305.2006.00006.x

22. Elyazar IRF, Gething PW, Patil AP et al. (2012) Plasmodium vivax malaria endemicity in Indonesia in 2010. PLos ONE 7 (5): e37325. doi: 10.1371/journal.pone.0037325
23. Rich SM, Leendertz FH, Xu G et al. (2009) The origin of malignant malaria. PNAS 106 (35): 14902 - 14907. doi: 10.1073pnas.0907740106.

24. Surjadjaja C, Surya A, Baird L (2016) Epidemiology of Plasmodium vivax in Indonesia. The American Journal of Tropical Medicine and Hygiene 95 (Suppl 6): 121 - 132. doi: 10.4269/ajtmh.16-0093.

25. Li Z, Zhang Q, Zheng C et l. (2016) Epidemiologic features of overseas imported malaria in the People's Republic of China. Malaria Journal 15: 141. doi: 10.1186/s12936-016-1188-7.

26. Prothero RM (1965) Migration and malaria. In: Prothero RM ed. Migrants and malaria in Africa. Pittsburgh, University of Pittsburgh Press.

27. Dharmawardena P, Premaratne RG, Gunasekera WMKTA (2015) Characterization of imported malaria, the largest threat to sustained malaria elimination from Sri Lanka. Malaria Journal 14: 177. doi: 10.1186/s12936-015-0697-0.

28. Deressa W, Ali A, Berhane Y (2006) Review of the interplay between population dynamics and malaria transmission in Ethiopia. Ethiopian Journal of Health Development 20 (3): 137 - 144. doi: 10.4314/ejhd.v20i3.46823.

29. Tatem A, Jia P, Ordanovich D et al. (2017) The geography of imported malaria to non-endemic countries: A meta-analysis of nationally reported statistics. The Lancet Infectious Diseases 17 (1): 98 - 107. doi: 10.1016/S1473-3099(16)30326-7.

30. Arwati H, Yotopranoto S, Rohmah AE, Safruddin D (2018) Submicroscopic malaria cases play role in local transmission in Trenggalek district, East Java Province, Indonesia. Malaria Journal 17: 2. doi: 10.1186/s12936-017-2147-7.

31. Sakti SAC (2017) Trenggalek adalah kabupaten terakhir di Jawa Timur yang belum bebas malaria, bagaimana bisa? http://jatim.tribunnews.com/. Accessed: 2 March 2018.

32. Wiyanti W (2018) Masih Ada 5 Provinsi di Indonesia yang Belum Eliminasi Malaria. https://health.detik.com/. Accessed: 20 August 2018. 